\title{
Correction to "Structure-Activity Relationships of the Main Bioactive Constituents of Euodia rutaecarpa on Aryl Hydrocarbon Receptor Activation and Associated Bile Acid Homeostasis"
}

\begin{abstract}
In the above article [Zhang Y, Yan T, Sun D, Xie C, Zheng Y, Zhang L, Yagai T, Krausz KW, Bisson WH, Yang X, and Gonzalez FJ (2018) Drug Metab Dispos 46(7):1030-1040; doi: https://doi.org/10.1124/ dmd.117.080176, was originally published under copyright by The American Society for Pharmacology and Experimental Therapeutics. The paper is U.S. Government work not protected by U.S. copyright. The article has been corrected to display the correct copyright in the HTML and PDF versions.

The compositor regrets this error and any inconvenience it has caused.
\end{abstract}

